\title{
Refractive Outcomes After LASIK for the Treatment of Mixed Astigmatism with the Allegretto WaveLight EX500
}

\author{
Majid Moshirfar (D) - Kathryn Durnford - Alin Megerdichian • \\ Andrew Thomson - Tanisha Martheswaran - William West Jr. • \\ Shannon McCabe $\cdot$ Yasmyne Ronquillo $\cdot$ Philip Hoopes
}

Received: October 22, 2021 / Accepted: January 26, 2022 / Published online: February 15, 2022

(C) The Author(s) 2022

\section{ABSTRACT}

Introduction: Treatment of mixed astigmatism with laser in situ keratomileusis (LASIK) is complex as the correction requires flattening the cornea in one meridian while steepening the cornea in the other meridian. The bitoric technique has become the most popular approach and has been tested across a variety of platforms. This study is the first to evaluate the

M. Moshirfar $(\bowtie) \cdot S$. McCabe $\cdot$ Y. Ronquillo .

P. Hoopes

Hoopes Vision, HDR Research Center,

Ophthalmology University of Utah Health Sciences

Center, 11820 S. State Street Suite \#200, Draper, UT 84020, USA

e-mail: cornea2020@me.com

S. McCabe

e-mail: shannonemccabe@gmail.com

Y. Ronquillo

e-mail: yronquillo@hoopesvision.com

P. Hoopes

e-mail: pch@hoopesvision.com

M. Moshirfar

Department of Ophthalmology and Visual Sciences, John A. Moran Eye Center, Salt Lake City, UT, USA

M. Moshirfar

Utah Lions Eye Bank, Murray, UT, USA results of mixed astigmatism treatment using the Allegretto WaveLight ${ }^{\circledR}$ EX500.

Methods: This study was a single-center, retrospective, noncomparative analysis of 400 eyes that underwent LASIK to correct for mixed astigmatism utilizing the EX500 excimer laser. Data on uncorrected distance visual acuity, corrected distance visual acuity, and spherical equivalent was analyzed at consecutive intervals $(1,3,6,9$, and 12 months). Refractive measurements were used to perform a vector analysis.

K. Durnford · W. West Jr.

School of Medicine, University of Utah, Salt Lake

City, UT, USAK. Durnford

e-mail: kathryn.durnford@hsc.utah.edu

W. West Jr.

e-mail: william.west@hsc.utah.edu

A. Megerdichian

College of Medicine, California Northstate

University, Elk Grove, CA, USA

e-mail: alin.megerdichian5900@cnsu.edu

\section{A. Thomson}

McGovern Medical School, Houston, TX, USA

e-mail: Andrew.C.Thomson@uth.tmc.edu

T. Martheswaran

Harvard University, Cambridge, MA, USA

e-mail: tmartheswaran@college.harvard.edu 
Results: Three and 12 months postoperatively, $71 \%$ and $74 \%$ of eyes had an uncorrected distance visual acuity (UDVA) of 20/20 or better and $99 \%$ and $100 \%$ of eyes had a UDVA of $20 / 40$ or better, respectively. The postoperative UDVA was within one line of the corrected distance visual acuity (CDVA) in 88\% and 93\% of eyes at 3 and 12 months, respectively. At 3 months, $78 \%$ of eyes achieved refractive astigmatism no greater than 0.50 diopters and at 12 months, $80 \%$ achieved this. The mean spherical equivalent refraction was $-0.36 \pm$ $0.57 \mathrm{D}$ at 12 months after surgery. At the 12-month follow-up, the mean refractive cylinder was reduced by $87 \%$, from -2.79 to -0.37 diopters. On vector analysis, $99 \%$ of eyes had an angle of error within $\pm 15^{\circ}$ from the intended target at 3 and 12 months.

Conclusion: Treatment of mixed astigmatism using the Allegretto WaveLight ${ }^{\circledR}$ EX500 laser exceeded the industry standards of safety, efficacy, stability, and accuracy.

Keywords: Ablation; Bitoric; Excimer lasers; Mixed astigmatism; Refractive errors; Refractive surgery

\section{Key Summary Points}

Why carry out this study?

This study was the largest retrospective review of mixed astigmatism treatment using laser in situ keratomileusis (LASIK).

This study is the first to report on the safety, efficacy, predictability, and stability of the Allegretto WaveLight ${ }^{\circledR}$ EX500 for the treatment of mixed astigmatism.

\section{What was learned from this study?}

The EX500 system showed excellent safety, efficacy, stability, and accuracy for the treatment of mixed astigmatism.
A review of previous publications established the excellent outcomes of this system as well as the need for a uniform approach to reporting outcomes of mixed astigmatism to better compare future studies.

Patients' satisfaction is very high compared to previous studies.

\section{INTRODUCTION}

The treatment of mixed astigmatism using laser in situ keratomileusis (LASIK) has challenged refractive surgeons. The goal of the surgical treatment of mixed astigmatism is to alter the two opposing meridians to form an image that focuses on the retina. To do so requires flattening one axis while steepening the other axis to achieve optimal results. The strategies used have included negative- and positive-cylinder nomograms, cross-cylinder, sequential, and bitoric ablations.

In 1998, Chayet et al. proposed the bitoric ablation profile, which flattens the steepest meridian with central cylindrical ablation and steepens the flattest meridian with a paracentral ablation [1]. The bitoric technique has become the most popular as it theoretically has less tissue removal than the other techniques [2]. Sheludchenko and Fadeykina investigated monotoric vs. bitoric ablation patterns and concluded that not only was there less regression in the bitoric ablation group but that the frequency of reoperation was also less (25\% vs. 44\%) [3]. Hassaballa et al. also studied the difference in monotoric and bitoric ablation patterns using the Technolas 217 and concluded that bitoric LASIK was safer, more effective, and more tissue-sparing [4].

The evolution of ablation approaches and laser technology has improved the refractive outcomes for these traditionally complex patients. There have been several studies published on the results of treating mixed astigmatism with LASIK across a variety of laser platforms, but this is the first study to publish 
on the results with the Allegretto WaveLight ${ }^{\circledR}$ EX500 (Alcon, Fort Worth, TX, USA). The purpose of this study is to report the efficacy, safety, predictability, and stability of this laser in the treatment of a large sample size of patients with mixed astigmatism.

\section{METHODS}

\section{Study Design}

This was a retrospective review of 400 eyes of 282 consecutive patients that underwent uneventful primary LASIK surgery at a single site for the correction of mixed astigmatism between January 2013 and April 2020 by four experienced surgeons using the WaveLight EX500 excimer laser. Data was collected at Hoopes Vision and retrieved from the SurgiVision DataLink database (SurgiVision Consultants Inc, Scottsdale, Arizona). All patients that had stable preoperative refraction for at least 2 years and had primary mixed astigmatism were included in the study. Patients with prior ocular surgery or trauma, a diagnosis of keratoconus, or another active ocular diagnosis (e.g., glaucoma, lens opacity, or dry eye disease) were excluded. This study was approved by the Hoopes Vision Ethics Board and adhered to the tenets outlined in the Declaration of Helsinki. The study was Health Insurance Portability and Accountability Act (HIPAA)-compliant, with a routine surgical informed consent obtained from all patients involved. It was an institutional review board (IRB)-approved study by the Biomedical Research Alliance of New York (BRANY, Lake Success, NY) in accordance with research standards and state law.

\section{Preoperative Evaluation}

All patients had a full preoperative ophthalmic examination which included uncorrected distance visual acuity (UDVA), corrected distance visual acuity (CDVA), manifest refraction, corneal pachymetry and topography, and slit lamp exam. Computed corneal topography and corneal pachymetry were measured with the
Pentacam $^{\circledR}$ HR (Oculus, Optikgeräte $\mathrm{GmbH}$, Wetzlar, Germany).

\section{Operative Technique}

Proparacaine drops were instilled prior to surgery. The corneal flap was created with Zeiss VisuMax (Carl Zeiss Meditec, Oberkochen, Germany), AMO iFs (Abbott Medical Optics, Santa Ana, California), or WaveLight ${ }^{\circledR}$ FS200 FS (Alcon Laboratories, Fort Worth, Texas) lasers. The flap diameter was between 8.5 and $9.0 \mathrm{~mm}$ and flap thickness was set to 100 or $115 \mu \mathrm{m}$ for all three FS lasers with the creation of a superior hinge. The WaveLight EX500 excimer laser system was used for stromal ablation with a 6.5$\mathrm{mm}$ central optical zone and blend zone to $9.0 \mathrm{~mm}$. Ablations were centered on the corneal apex using the wavefront-optimized protocol. In accordance with the bitoric ablation technique, in the first direction, the paracentral cornea was steepened, and, in the second direction, the surface was flattened following removal of tissue from the central cornea.

\section{Postoperative Care and Evaluation}

The postoperative treatment protocol included ofloxacin $0.3 \%$ or moxifloxacin $0.5 \%$ four times a day for 1 week. Patients were instructed to apply prednisolone acetate $1 \%$ every hour while awake for the first $24 \mathrm{~h}$. On postoperative day 1 , the prednisolone was decreased to four times daily for 1 week and subsequently stopped. Patients were followed at 1 day, 1 month, 3 months, 6 months, and 12 months. Results at 3 months and 12 months were used for postoperative analysis. At all postoperative visits, UDVA was assessed and documented. Manifest refraction was performed at all postoperative visits after 1 month.

\section{Statistical Analysis}

Outcomes at 3 months and 12 months were assessed according to the standard graphs for reporting astigmatism outcomes of refractive surgery outlined in the Journal of Refractive Surgery [5]. The data were compiled for 3 and 
12 months and were plotted on the nine standard graphs with Excel (Microsoft Corporation, Seattle, WA, USA). Vector analysis was performed on the basis of methodology provided by Alpins [6] and Eydelman et al. [7] to produce polar diagrams with the assistance of the ASSORT $^{\circledR}$ Group Analysis Calculator. Visual acuity was converted to logarithm of the minimal angle of resolution (logMAR) to obtain a mean and standard deviation (SD). Continuous variables are presented as mean $\pm S D$ with range. The Shapiro-Wilk test was used to test for normality. The refractive outcomes did not follow normal Gaussian distribution, so the differences in refractive errors pre- and postLASIK were compared with the paired Wilcoxon signed-rank test. A $p$ value of less than 0.05 was considered statistically significant. Statistical analysis was performed using $\mathrm{R}$ version 4.1.0 (2021-05-18) statistical software.

\section{RESULTS}

The preoperative data were documented for 400 eyes. Of these 400, 344 (86.0\%) had data available from the 3-month postoperative visit and 179 had data available from the 12-month postoperative visit. The demographic data of the study population is available in Table 1 . The preoperative and postoperative refractive outcomes over 3 and 12 months are available in Table 2, which highlights the improvement in refractive astigmatism after LASIK. The improvement in the 3- and 12-month postoperative refractive cylinders compared with the

Table 1 Demographics of the study population

\begin{tabular}{llr}
\hline & Mean \pm SD & Range \\
\hline Age (years) & $38.3 \pm 10.1$ & 19,85 \\
\hline & $n$ & $(\%)$ \\
\hline Gender (M/F) & $181 / 101$ & $(64.2 \%, 35.8 \%)$ \\
Eyes (OD/OS) & $193 / 207$ & $(48.3 \%, 51.8 \%)$
\end{tabular}

$F$ female, $M$ male, $O D$ right eye, $O S$ left eye, $S D$ standard deviation preoperative refractive cylinder was statistically significant $(p<0.001)$. The 3-month compared with the 12-month postoperative refractive cylinders did not vary significantly.

The standard graphs for reporting safety, efficacy, predictability, and stability during the postoperative period at 3 and 12 months are shown in Fig. 1. At 3 months postoperatively, UDVA was $20 / 20$ or better for $71 \%$ of eyes and $99 \%$ of eyes had UDVA was $20 / 40$ or better (Fig. 1a). The UDVA was $20 / 20$ or better for $74 \%$ of eyes relative to the $100 \%$ of eyes that had a UDVA of $20 / 40$ or better at 12 months postoperatively (Fig. 1a). The spherical equivalent (SEQ) was at most $0.50 \mathrm{D}$ of the intended target for $88 \%$ of patients at 12 months postoperatively and $100 \%$ of patients were within $1.00 \mathrm{D}$ of the intended SEQ at 12 months (Fig. 1e). Regarding the safety of the procedure, at 3 and 12 months, $0 \%$ of patients lost two or more lines of CDVA compared with their preoperative CDVA. There was a gain of one line for $25 \%$ of patients at 12 months, there was no change for $72 \%$ of patients, and $3 \%$ of patients lost one line (Fig. 1c). The postoperative refraction remained stable between 3 and 12 months with a mean of $-0.35 \pm 0.54$ at 3 months and a mean of $-0.36 \pm 0.57$ at 12 months (Fig. 1f). Figure $1 \mathrm{~d}$ shows that the attempted postoperative outcomes were generally predictable, with a slight undercorrection shown with the slopes of 0.95 for 3 months and 0.96 for 12 months.

The evaluation for the correction of astigmatism is demonstrated with the histogram of the angle of error, which shows that the angle applied was consistent with the intended axis as the angle of error did not exceed $15^{\circ}$ for any eyes (Fig. 1i). A negative value indicates a clockwise rotational error and a positive value indicates the opposite. Vector analysis was carried out with refractive measures not adjusted to the corneal plane. The correction index (CI), which is defined as the ratio of surgically induced astigmatism (SIA) to target induced astigmatism (TIA), indicates the amount of under- or overcorrection of astigmatism and is ideally equal to one. The geometric mean of CI at 3 months was 0.96 (range $0.30,1.39$ ) and 0.93 (range $0.21,1.77$ ) at 12 months, denoting overall astigmatism undercorrection of $4 \%$ and 
Table 2 Preoperative, 3-month, and 12-month refractive outcomes

\begin{tabular}{|c|c|c|c|c|c|c|}
\hline & \multicolumn{2}{|c|}{ Preoperative $(n=400)$} & \multicolumn{2}{|c|}{3 months postop $(n=344)$} & \multicolumn{2}{|c|}{12 months postop $(n=179)$} \\
\hline & Mean \pm SD & Range & Mean \pm SD & Range & Mean \pm SD & Range \\
\hline Refractive sphere (D) & $+0.79 \pm 0.90$ & $\begin{array}{l}-1.00 \\
+5.00\end{array}$ & $-0.15 \pm 0.55$ & $\begin{array}{c}-2.25 \\
1.50\end{array}$ & $-0.18 \pm 0.57$ & $\begin{aligned}- & 2.00 \\
& +1.00\end{aligned}$ \\
\hline $\begin{array}{l}\text { Refractive cylinder } \\
\text { (D) }\end{array}$ & $-2.79 \pm 1.31$ & $\begin{array}{r}-6.75 \\
-1.00\end{array}$ & $-0.40 \pm 0.37$ & $\begin{array}{c}-2.00 \\
0.00\end{array}$ & $-0.37 \pm 0.34$ & $-1.75,0.00$ \\
\hline MRSE \pm SD & $-0.61 \pm 0.70$ & $\begin{aligned}- & 2.63 \\
+ & 1.88\end{aligned}$ & $-0.35 \pm 0.54$ & $\begin{array}{c}-2.50 \\
1.13\end{array}$ & $-0.36 \pm 0.57$ & $\begin{array}{l}-2.13 \\
+0.75\end{array}$ \\
\hline CDVA (logMAR) & $0.00 \pm 0.04$ & $-0.12,0.30$ & $-0.02 \pm 0.05$ & $\begin{array}{c}-0.12 \\
0.18\end{array}$ & $-0.01 \pm 0.05$ & $-0.12,0.18$ \\
\hline UDVA (logMAR) & - & - & $0.08 \pm 0.21$ & $\begin{array}{c}-0.12 \\
1.10\end{array}$ & $0.08 \pm 0.21$ & $-0.12,1.00$ \\
\hline
\end{tabular}

$C D V A$ corrected distance visual acuity, $D$ diopters, $\log M A R$ logarithm of the minimal angle of resolution, $M R S E$ manifest refraction spherical equivalent, $U D V A$ uncorrected distance visual acuity

$7 \%$ at 3 and 12 months, respectively (Fig. $1 \mathrm{~h}$ ). The difference vector (DV) represents additional induced astigmatism and is equivalent to the postoperative cylinder. Polar diagrams of 3- and 12-month TIA and DV are displayed in plus cylinder notation. Reduction in vector magnitudes seen between TIA and DV diagrams shown in Fig. 2 represent excellent astigmatism correction achieved by flattening the steep meridian of the cornea.

\section{DISCUSSION}

The current study showed that LASIK performed with the WaveLight EX500 excimer laser has remarkable efficacy, safety, predictability, and stability for the treatment of mixed astigmatism. From our thorough review of the current literature, it is evident that the LASIK treatment of mixed astigmatism is significantly underreported compared to those for myopia and hyperopia. Within the past two decades, our study is the first to present a sample of this size and one of the few to report over a 12-month follow-up period. In 2014, Bohac et al. reported on the use of the Allegretto Eye-Q (61 eyes) vs. the Amaris (111 eyes) with a 12-month follow-up period and in
2017 Alpins et al. reviewed 242 eyes over a 12 -month period $[8,9]$. Patel et al., in a similar fashion to Bohac et al., reported on the refractive outcome differences between the AllegrettoEye-Q and Schwind Amaris platforms in moderate to high astigmatism [10]. A review of prior publications evaluating the treatments of mixed astigmatism is shown in Table 3.

In this study there was a mean cylinder reduction rate of $86.8 \%$ at 12 months, exceeding the astigmatic reduction achieved by the majority of reported studies within the past two decades (Fig. 3). Almost 75\% of eyes achieved a UDVA of $20 / 20$ or better by 12 months after surgery and $100 \%$ achieved a UDVA or $20 / 40$ or better. Other studies report a range of postoperative UDVA of $20 / 20$ or better from $18.0 \%$ [11] to $100 \%$ [12]. The study demonstrated that by 12 months, $88 \%$ of patients had an SEQ no greater than $0.50 \mathrm{D}$ of their intended SEQ target. There was high treatment safety as no patient lost two or more lines of CDVA, which is consistent with many of the previous studies [8, 12-21]. At 12 months postoperatively, $80.8 \%$ of patients had a refractive cylinder no greater than $0.50 \mathrm{D}$ and $100 \%$ had cylinders no greater 


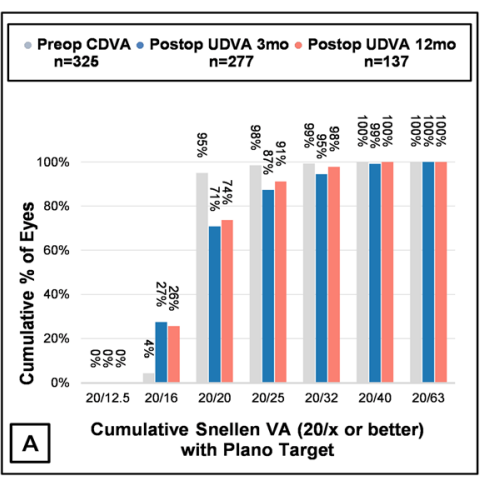

Uncorrected Distance Visual Acuity

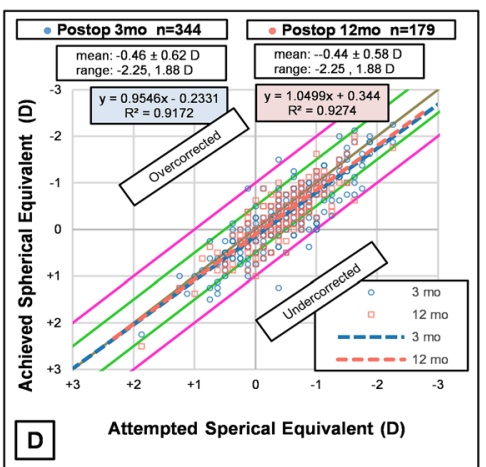

Spherical Equivalent Refraction Attempted vs Achieved

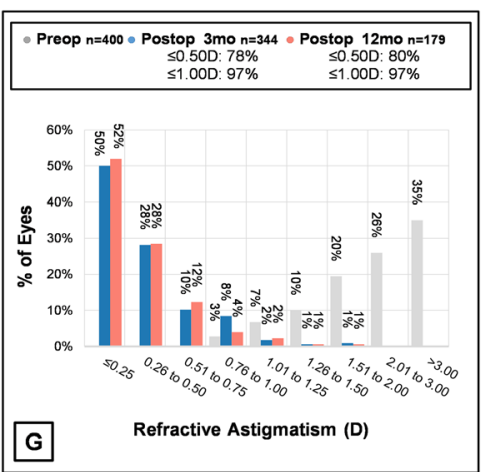

Refractive Astigmatism

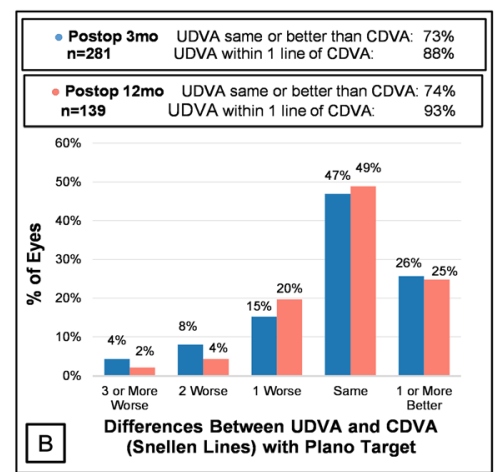

Uncorrected Distance Visual Acuity vs. Corrected Distance Visual Acuity

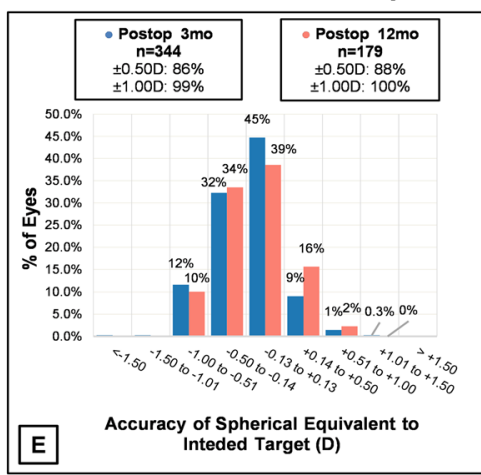

Spherical Equivalent Refraction Accuracy

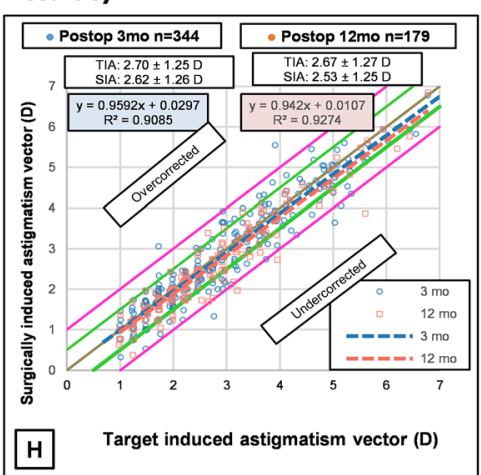

Target Induced Astigmatism vs Surgically Induced Astigmatism

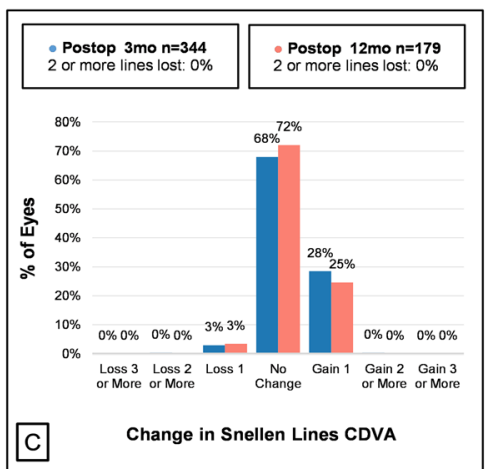

Change in Corrected Distance Visual Acuity

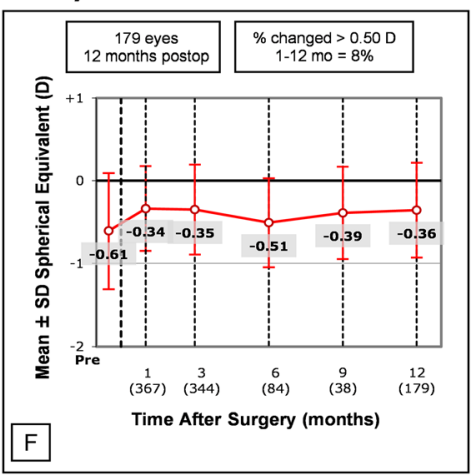

Spherical Equivalent Refraction Stability

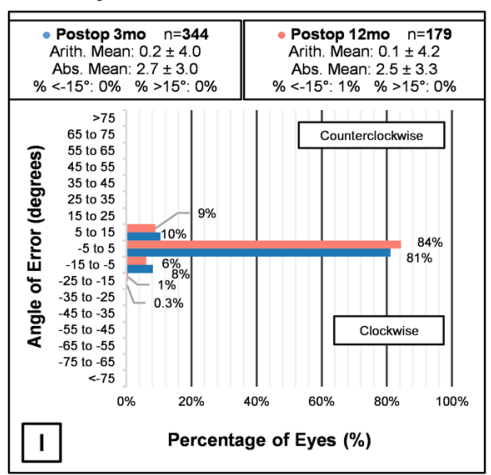

Refractive Astigmatism Angle of Error
Fig. 1 The nine standard graphs for reporting refractive surgical outcomes show the visual $(\mathbf{a}-\mathbf{c})$, refractive $(\mathbf{d}-\mathbf{e})$, and astigmatism $(\mathbf{f}-\mathbf{i})$ outcomes for the 400 patients with mixed astigmatism treated using the Allegretto WaveLight $^{\circledR}$ EX500 excimer laser (Alcon, Fort Worth, TX,

than $1.00 \mathrm{D}$ of astigmatism. In some reports, fewer than $60 \%$ of patients had a refractive cylinder no greater than $0.50 \mathrm{D}$ $[15,19,21,22]$, but only one study reported fewer than $60 \%$ of patients having a refractive
USA). $C D V A$ corrected distance visual acuity, $D$ diopters, postop postoperative, preop preoperative, SIA surgically induced astigmatism, TIA target induced astigmatism, $U D V A$ uncorrected distance visual acuity

cylinder no greater than $1.00 \mathrm{D}$ [19]. Our results suggest that our findings are consistent with previous studies and showed improvement on other variables such as the mean reduction in refractive cylinder. 


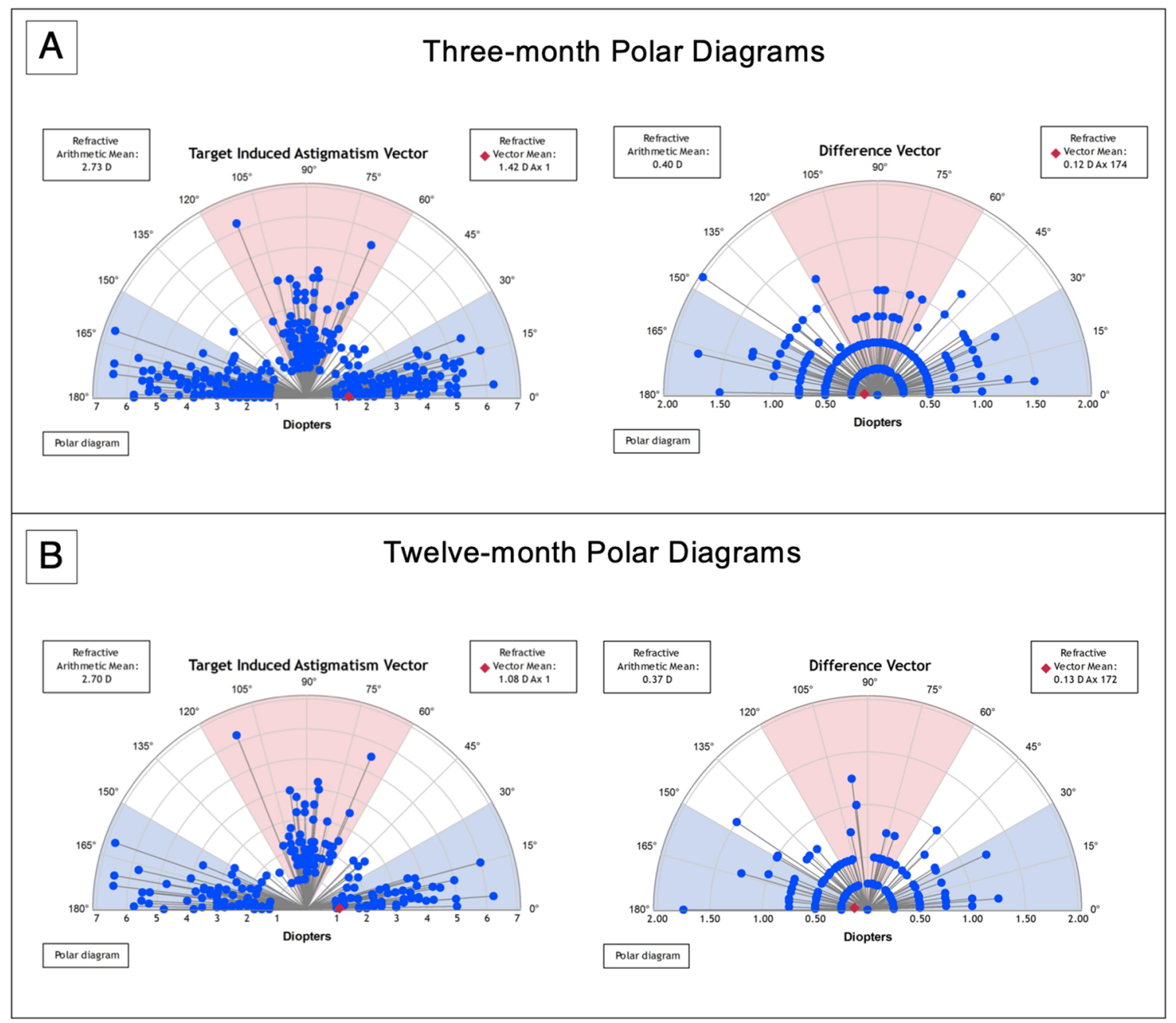

Fig. 2 Vector analysis showing the refractive cylinder as polar plots for target induced astigmatism and difference vector. $D$ diopters

There have been multiple publications suggesting a method of standardizing the evaluation of refractive surgeries $[5,7,23]$ but these recommendations were made during the time in which these studies were completed. As is evident in Table 3 , it is difficult to make comparisons across the studies because there have not been variables that were routinely reported across all publications. Reinstein et al. made the most recent of these recommendations, which is to report refractive surgery results in the form of nine standardized graphs and has been widely adopted by many authors [5]. As a consistent vocabulary for defining success of refractive surgeries is applied broadly, more studies can better compare their results against historical data.

Limitations in our current study include the retrospective nature of the data and loss of follow-up data at 12 months. A prospective analysis to study the refractive outcomes of LASIK on mixed astigmatism is recommended. A thorough analysis of refractive regression and the need for re-treatment may provide further insight into the efficacy of the Allegretto WaveLight ${ }^{\circledR}$ EX500 excimer laser system. 
Table 3 Comparison of results for mixed astigmatism treated with various laser systems

\begin{tabular}{|c|c|c|c|c|c|c|c|c|c|c|c|}
\hline Study & Device & $\underset{(\mathrm{mos})}{\mathrm{FU}}$ & $\begin{array}{c}n \\
\text { (eyes) }\end{array}$ & $\begin{array}{c}\text { Preop } \\
\text { Sphere (D) }\end{array}$ & $\begin{array}{c}\text { Preop } \\
\text { Cylinder (D) }\end{array}$ & $\begin{array}{c}\text { Postop } \\
\text { Cylinder (D) }\end{array}$ & $\begin{array}{c}\text { Mean } \\
\text { Reduction in } \\
\text { Refractive } \\
\text { Cylinder }\end{array}$ & $\begin{array}{c}\text { Postop UDVA } \\
20 / 20\end{array}$ & $\begin{array}{l}\text { Loss of } \bullet \\
1 \text { line } \\
\text { CDVA }\end{array}$ & $\begin{array}{l}\text { Loss of } \bullet 2 \\
\text { lines CDVA }\end{array}$ & $\begin{array}{c}\text { Refractive } \\
\text { Astigmatism } \\
\bullet 0.50 \mathrm{D}\end{array}$ \\
\hline $\begin{array}{l}\text { Chayet et al. } \\
\text { (2001) }\end{array}$ & $\begin{array}{l}\text { NIDEK EC- } \\
5000\end{array}$ & 12 & 47 & $\begin{array}{l}+1.31 \pm \\
0.95\end{array}$ & $-4.02 \pm 1.22$ & $-0.35 \pm 0.42$ & $91.3 \%$ & $68.0 \%$ & $0.0 \%$ & $0.0 \%$ & NS \\
\hline \multirow{2}{*}{$\begin{array}{l}\text { Sheludchenko } \\
\text { et al. (2001) }\end{array}$} & $\begin{array}{l}\text { NIDEK EC- } \\
5000\end{array}$ & 6 & 18 & $\begin{array}{c}+1.43 \pm \\
0.22\end{array}$ & $-4.05 \pm 0.64$ & $-1.89 \pm 0.39$ & $53.3 \%$ & NS & NS & NS & NS \\
\hline & $\begin{array}{l}\text { NIDEK EC- } \\
5000\end{array}$ & 6 & 28 & $\begin{array}{c}+1.37 \pm \\
0.18 \\
\end{array}$ & $-4.15 \pm 0.86$ & $-1.49 \pm 0.24$ & $64.1 \%$ & NS & NS & NS & NS \\
\hline $\begin{array}{l}\text { Salz et al. } \\
\text { (2002) }\end{array}$ & LADARVision & 12 & 57 & $\begin{array}{c}+1.85 \pm \\
1.35\end{array}$ & $-3.26 \pm 1.49$ & NS & NS & $47.2 \%$ & NS & $0.0 \%$ & NS \\
\hline $\begin{array}{l}\text { Rueda et al. } \\
\quad(2002)\end{array}$ & $\begin{array}{l}\text { NIDEK EC- } \\
5000\end{array}$ & 6 & 23 & NS & $-3.38 \pm 1.10$ & $-0.59 \pm 0.46$ & $82.5 \%$ & $18.0 \%$ & NS & NS & NS \\
\hline \multirow{2}{*}{$\begin{array}{l}\text { Hassaballa et } \\
\text { al. (2003) }\end{array}$} & $\begin{array}{c}\text { Technolas } \\
217 \mathrm{C}\end{array}$ & 6 & 15 & NS & $-2.80 \pm 1.00$ & $-0.98 \pm 0.60$ & $65.0 \%$ & NS & $13.3 \%$ & $13.3 \%$ & NS \\
\hline & $\begin{array}{l}\text { Technolas } \\
217 \mathrm{C}\end{array}$ & 6 & 15 & NS & $-4.05 \pm 0.68$ & $-0.76 \pm 0.57$ & $81.2 \%$ & NS & $13.3 \%$ & $6.7 \%$ & NS \\
\hline $\begin{array}{l}\text { Albarran-Diego } \\
\text { et al. (2004) }\end{array}$ & Technolas 217 & 6 & 28 & NS & $-4.04 \pm 1.13$ & $-0.67 \pm 0.79$ & $83.4 \%$ & $21.4 \%$ & $10.7 \%$ & $0.0 \%$ & $57.1 \%$ \\
\hline Jin et al. (2005) & $\begin{array}{c}\text { LADARVision } \\
4000\end{array}$ & 12 & 64 & $\begin{array}{c}+1.14 \pm \\
0.84\end{array}$ & $-2.72 \pm 0.89$ & $-0.60 \pm 0.46$ & $77.9 \%$ & $58.3 \%$ & $5.0 \%$ & $1.6 \%$ & $56.3 \%$ \\
\hline $\begin{array}{l}\text { Pinelli et al. } \\
\text { (2006) }\end{array}$ & Technolas 217 & 12 & 40 & NS & NS & NS & NS & NS & $0.0 \%$ & $0.0 \%$ & $80.0 \%$ \\
\hline $\begin{array}{l}\text { de Ortueta et } \\
\text { al. (2008) }\end{array}$ & ESIRIS & 12 & 19 & $\begin{array}{c}+1.63 \pm \\
1.23\end{array}$ & $-3.55 \pm 1.17$ & $-0.61 \pm 0.48$ & $82.8 \%$ & $31.0 \%$ & $6.0 \%$ & $0.0 \%$ & $85.0 \%$ \\
\hline \multirow{3}{*}{$\begin{array}{l}\text { Khalifa et al. } \\
\text { (2009) }\end{array}$} & $\begin{array}{c}\text { VISX Star S4 } \\
\text { (Conventional) }\end{array}$ & 3 & 20 & $\begin{array}{l}+1.67 \pm \\
1.32\end{array}$ & $-2.79 \pm 2.24$ & NS & NS & $65.0 \%$ & $15.0 \%$ & $10.0 \%$ & $60.0 \%$ \\
\hline & $\begin{array}{l}\text { VISX Star S4 } \\
\text { (WFG) }\end{array}$ & 3 & 20 & $\begin{array}{c}+1.27 \pm \\
0.60\end{array}$ & $-3.34 \pm 1.48$ & NS & NS & $70.0 \%$ & $10.0 \%$ & $0.0 \%$ & $65.0 \%$ \\
\hline & $\begin{array}{l}\text { VISX Star S4 } \\
(\text { WFG + IR) }\end{array}$ & 3 & 20 & $\begin{array}{c}+1.00 \pm \\
1.69\end{array}$ & $-2.50 \pm 5.60$ & NS & NS & $90.0 \%$ & $0.0 \%$ & $0.0 \%$ & $80.0 \%$ \\
\hline
\end{tabular}

\begin{tabular}{|c|c|c|c|c|c|c|c|c|c|c|c|}
\hline \multirow{2}{*}{$\begin{array}{l}\text { Stonecipher et } \\
\text { al. (2010) }\end{array}$} & $\begin{array}{c}\text { Allegretto } \\
\text { WAVE } 200-\mathrm{Hz}\end{array}$ & 6 & 111 & & $-1.06 \pm 0.90$ & & & $79.3 \%$ & & NS & \\
\hline & $\begin{array}{c}\text { Allegretto } \\
\text { WAVE } 400-\mathrm{Hz}\end{array}$ & 6 & 26 & NS & $-2.55 \pm 0.15$ & NS & NS & $80.8 \%$ & $0.0 \%$ & NS & $100.0 \%$ \\
\hline $\begin{array}{l}\text { Tanzer et al. } \\
\text { (2013) }\end{array}$ & $\begin{array}{l}\text { VISX Star S4 } \\
(\text { WFG + IR) }\end{array}$ & 3 & 60 & NS & NS & NS & NS & $100.0 \%$ & $0.0 \%$ & $0.0 \%$ & NS \\
\hline $\begin{array}{l}\text { Alió et al. } \\
\text { (2013) }\end{array}$ & Amaris & 3 & 52 & $\begin{array}{l}+2.41 \pm \\
1.26\end{array}$ & $-3.89 \pm 0.70$ & $-1.11 \pm 0.67$ & $71.5 \%$ & NS & $15.4 \%$ & $5.8 \%$ & NS \\
\hline \multirow{2}{*}{$\begin{array}{l}\text { Bohac et al. } \\
\quad(2014)\end{array}$} & $\begin{array}{c}\text { Allegretto Eye- } \\
\text { Q }\end{array}$ & 12 & 61 & $\begin{array}{c}+2.72 \pm \\
1.79\end{array}$ & $-3.84 \pm 1.21$ & $-0.85 \pm 0.41$ & $77.9 \%$ & NS & $0.0 \%$ & $0.0 \%$ & NS \\
\hline & Amaris & 12 & 111 & $\begin{array}{c}+3.11 \pm \\
1.57\end{array}$ & $-3.66 \pm 1.16$ & $-0.58 \pm 0.38$ & $84.2 \%$ & NS & $0.0 \%$ & $0.0 \%$ & NS \\
\hline \multirow{2}{*}{$\begin{array}{l}\text { Kilavuzo lu et } \\
\text { al. (2016) }\end{array}$} & $\begin{array}{c}\text { Allegretto } \\
\text { WAVE } 400-\mathrm{Hz}\end{array}$ & 3 & 28 & $\begin{array}{c}+1.58 \pm \\
1.02\end{array}$ & $-3.19 \pm 1.19$ & $-0.92 \pm 0.28$ & $71.1 \%$ & $20.0 \%$ & $0.0 \%$ & $0.0 \%$ & $10.0 \%$ \\
\hline & $\begin{array}{c}\text { Technolas } \\
217 \mathrm{z}\end{array}$ & 3 & 46 & $\begin{array}{c}+1.67 \pm \\
1.43\end{array}$ & $-3.62 \pm 1.42$ & $-0.88 \pm 0.09$ & $67.7 \%$ & $33.3 \%$ & $0.0 \%$ & $0.0 \%$ & $33.3 \%$ \\
\hline $\begin{array}{l}\text { Alpins et al. } \\
\text { (2017) }\end{array}$ & $\begin{array}{l}\text { VISX Star S4 } \\
\text { (WFG + IR) }\end{array}$ & 12 & 242 & NS & NS & NS & NS & $38.0 \%$ & $14.0 \%$ & $5.0 \%$ & $68.0 \%$ \\
\hline $\begin{array}{l}\text { Reinstein et al. } \\
(2018)\end{array}$ & $\begin{array}{c}\text { VisuMax MEL } \\
90\end{array}$ & & 105 & $\begin{array}{c}+1.17 \pm \\
0.99\end{array}$ & $-2.93 \pm 1.47$ & $-0.55 \pm 0.41$ & $81.2 \%$ & $73.0 \%$ & $10.0 \%$ & $0.0 \%$ & $65.0 \%$ \\
\hline $\begin{array}{l}\text { Stanca et al. } \\
\text { (2018) }\end{array}$ & $\begin{array}{c}\text { VisuMax MEL } \\
80\end{array}$ & 12 & 74 & $\begin{array}{c}+1.88 \pm \\
1.31\end{array}$ & $-4.17 \pm 1.09$ & $-1.19 \pm 0.65$ & $71.5 \%$ & $64.9 \%$ & $0.0 \%$ & $0.0 \%$ & $18.9 \%$ \\
\hline Current Study & $\begin{array}{c}\text { Allegretto } \\
\text { WaveLight } \\
\text { EX500 }\end{array}$ & 12 & 400 & $\begin{array}{c}+0.79 \pm \\
0.90\end{array}$ & $-2.79 \pm 1.31$ & $-0.37 \pm 0.34$ & $86.8 \%$ & $74.1 \%$ & $3.3 \%$ & $0.0 \%$ & $80.4 \%$ \\
\hline
\end{tabular}

The color scale shown indicates ideal values in green for each category and scales to white for less-than-ideal values.

$\mathrm{CDVA}=$ corrected distance visual acuity, $\mathrm{D}=$ diopters, $\mathrm{FU}=$ follow-up, $\mathrm{mos}=$ months, NS = not specified, UDVA = uncorrected distance visual acuity

\section{CONCLUSIONS}

In 2006, the Allegretto WAVE Excimer Laser System was approved by the FDA (P030008, Supplement number S004) for the reduction or elimination of naturally occurring mixed astigmatism up to $6.00 \mathrm{D}$. Our study is the largest study to date on the treatment of mixed astigmatism. It also has one of the highest patient satisfaction compared with previous studies. 


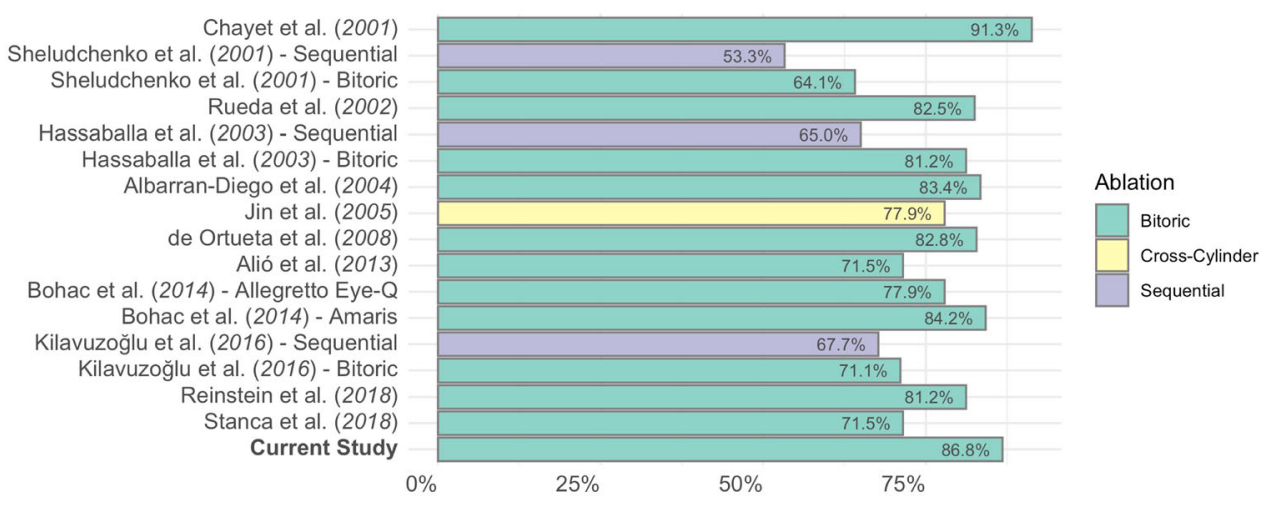

Fig. 3 Comparison of the mean reduction in cylinder across publications on the treatment of mixed astigmatism. For publications with multiple results, the variable being compared within the study is indicated

From this study, we conclude that the WaveLight EX500 excimer laser meets the standards of safety, efficacy, predictability, and accuracy for the treatment of mixed astigmatism using standard LASIK.

\section{ACKNOWLEDGEMENTS}

We thank the patients who were part of this retrospective study.

Funding. No funding or sponsorship was received for this study or the publication of this article.

Authorship. All named authors meet the International Committee of Medical Journal Editors (ICMJE) criteria for authorship for this article, take responsibility for the integrity of the work as a whole, and have given their approval for this version to be published.

Author Contributions. Majid Moshirfar: Concept, design, analysis. Kathryn Durnford: writing the manuscript, statistical analysis, Alin Megerdichian: drafting the manuscript, analysis. Andrew Thomson: data gathering, drafting the manuscript. Tanisha Martheswaran: analysis, William West Jr: Data gathering, drafting the manuscript. Shannon McCabe: analysis and final writing of the manuscript. Yasmyne C. Ronquillo: Design, final writing, scientific and technical editing, analysis. Phillip Hoopes: Analysis, administrative.

Disclosures. Majid Moshirfar, Kathryn Durnford, Alin Megerdichian, Andrew Thomson, Tanisha Martheswaran, William West Jr, Shannon McCabe, Yasmyne C. Ronquillo and Phillip Hoopes confirm that they have no conflicts of interest to disclose.

Compliance with Ethics Guidelines. This study was approved by the Hoopes Vision Ethics Board and adhered to the tenets outlined in the Declaration of Helsinki. The study was HIPAAcompliant, with a routine surgical informed consent obtained from all patients involved. It was an IRB-approved study by the Biomedical Research Alliance of New York (BRANY, Lake Success, NY) in accordance with research standards and state law.

Data Availability. Data sharing is not applicable to this article as no datasets were generated.

Open Access. This article is licensed under a Creative Commons Attribution-NonCommercial 4.0 International License, which permits any non-commercial use, sharing, adaptation, distribution and reproduction in any medium or format, as long as you give appropriate credit to the original author(s) and the source, provide a link to the Creative Commons licence, and indicate if changes were made. The images or 
other third party material in this article are included in the article's Creative Commons licence, unless indicated otherwise in a credit line to the material. If material is not included in the article's Creative Commons licence and your intended use is not permitted by statutory regulation or exceeds the permitted use, you will need to obtain permission directly from the copyright holder. To view a copy of this licence, visit http://creativecommons.org/licenses/by$\mathrm{nc} / 4.0 /$.

\section{REFERENCES}

1. Chayet AS, Magallanes R, Montes M, Chavez S, Robledo N. Laser in situ keratomileusis for simple myopic, mixed, and simple hyperopic astigmatism. J Refract Surg. 1998. https://doi.org/10.3928/1081597x-19980401-05.

2. Vinciguerra P, Sborgia M, Epstein D, Azzolini M, MacRae S. Photorefractive keratectomy to correct myopic or hyperopic astigmatism with a crosscylinder ablation. J Refract Surg. 1999. https://doi. org/10.3928/1081-597X-19990302-04.

3. Sheludchenko VM, Fadeykina T. Comparative results between standard and bitoric nomograms for astigmatism correction. J Refract Surg. 2001. https://doi.org/10.3928/1081-597x-20010302-20.

4. Hassaballa MA, Ayala MJ, Alió JL. Laser in situ keratomileusis correction of mixed astigmatism by bitoric ablation. J Cataract Refract Surg. 2003;29(10):1889-95. https://doi.org/10.1016/ S0886-3350(03)00071-3.

5. Reinstein DZ, Archer TJ, Randleman JB. JRS standard for reporting astigmatism outcomes of refractive surgery. J Refract Surg. 2014. https://doi.org/10. 3928/1081597X-20140903-01.

6. Alpins N. Astigmatism analysis by the Alpins method. J Cataract Refract Surg. 2001. https://doi. org/10.1016/S0886-3350(00)00798-7.

7. Eydelman MB, Drum B, Holladay J, et al. Standardized analyses of correction of astigmatism by laser systems that reshape the cornea. J Refract Surg. 2006. 20060101-16

8. Bohac M, Biscevic A, Koncarevic M, Anticic M, Gabric N, Patel S. Comparison of Wavelight Allegretto Eye-Q and Schwind Amaris 750S excimer laser in treatment of high astigmatism. Graefes
Arch Clin Exp Ophthalmol. 2014. https://doi.org/ 10.1007/s00417-014-2776-2.

9. Alpins N, Ong JKY, Stamatelatos G. Planning for coupling effects in bitoric mixed astigmatism ablative treatments. J Refract Surg. 2017. https://doi. org/10.3928/1081597X-20170616-01.

10. Patel S, Bohac M, Biscevic A, Koncarevic M, Anticic M, Gabric N. A critical evaluation of refractive outcomes following LASIK for moderate to high astigmatism using two excimer laser platforms. J Refract Surg. 2017;33(2):104-9. https://doi.org/10. 3928/1081597X-20161102-01.

11. Rueda L, Pineda-Fernández A, Huang D, Nur J. Laser in situ keratomileusus for mixed and simple myopic astigmatism with the Nidek EC-5000 laser. J Refract Surg. 2002;18(3)234-8.

12. Tanzer DJ, Brunstetter $\mathrm{T}$, Zeber R, et al. Laser in situ keratomileusis in United States naval aviators. J Cataract Refract Surg. 2013. https://doi.org/10. 1016/j.jcrs.2013.01.046.

13. Chayet AS, Montes M, Gómez L, Rodríguez X, Robledo N, MacRae S. Bitoric laser in situ keratomileusis for the correction of simple myopic and mixed astigmatism. Ophthalmology. 2001;108(2):

303-8. https://doi.org/10.1016/S01616420(00)00498-X.

14. Salz JJ, Stevens CA. LASIK correction of spherical hyperopia, hyperopic astigmatism, and mixed astigmatism with the LADARVision excimer laser system. Ophthalmology. 2002. https://doi.org/10. 1016/S0161-6420(02)01133-8.

15. Albarrán-Diego C, Muñoz G, Montés-Micó R, Alió JL. Bitoric laser in situ keratomileusis for astigmatism. J Cataract Refract Surg. 2004;30(7):1471-8. https://doi.org/10.1016/j.jcrs.2003.11.054.

16. Pinelli R, Ngassa EN, Scaffidi E. Sequential ablation approach to the correction of mixed astigmatism. J Refract Surg. 2006. https://doi.org/10.3928/1081597x-20061001-09.

17. De Ortueta D, Haecker C. Laser in situ keratomileusis for mixed astigmatism using a modified formula for bitoric ablation. Eur J Ophthalmol. 2008. https://doi.org/10.1177/ 112067210801800603.

18. Khalifa M, El-Kateb M, Shaheen MS. Iris registration in wavefront-guided LASIK to correct mixed astigmatism. J Cataract Refract Surg. 2009. https://doi. org/10.1016/j.jcrs.2008.11.039.

19. Kilavuzoğlu AE, Gönen T, Çelebı ARC, Coşar Yurterı $\mathrm{CB}$, Şener AB. Treatment of mixed astigmatism: early clinical outcomes with WaveLight and 
Technolas excimer lasers. Turkish J Med Sci. 2016. https://doi.org/10.3906/sag-1504-35.

20. Reinstein DZ, Carp GI, Archer TJ, Day AC, Vida RS. Outcomes for mixed cylinder LASIK with the MEL $90 ®$ excimer laser. J Refract Surg. 2018. https://doi. org/10.3928/1081597X-20180814-01.

21. Stanca HT, Munteanu M, Jianu DC, et al. Femtosecond-LASIK outcomes using the VisuMax ${ }^{\circledR}-$ MEL ${ }^{\circledR} 80$ platform for mixed astigmatism refractive surgery. Rom J Morphol Embryol. 2018;59(1):277-83.

22. Jin GJC, Merkley KH, Lyle WA. Laser in situ keratomileusis for primary and secondary mixed astigmatism. Am J Ophthalmol. 2005. https://doi. org/10.1016/j.ajo.2005.01.048.

23. Waring GO 3rd. Standard graphs for reporting refractive surgery. J Refract Surg. 2000;16(4): 459-66. 